\title{
Implementation of the Death Penalty in the Perspective of Human Rights in Indonesia
}

\author{
La Sina \\ Faculty of Law, Mulawarman University \\ Jln. Sambaliung, Kampus Gunung Kelua, Samarinda 75119, East Kalimantan, Indonesia \\ Tel./Fax:+62-541-7774144 E-mail:Lasinaunmul@gmail.com
}

Submitted: Jul 8, 2016; Reviewed: Oct 28, 2016; Accepted: Nov 11, 2016

\begin{abstract}
The 1945 Constitution of Indonesia provides for rights to life and to remain free from torture that are fundamental human rights that shall not be curtailed under any circumstance. Since 1945, Indonesia does not regulate the protection of the right of life to the citizens. Until 1946, enacted Law No. 1 of 1946 concerning the Indonesian Criminal Code which in several provisions concerning the death penalty. Death sentences and executions in Indonesia is always debatable. However, it is still implemented and can not be avoided, unless the change of its legal provisions. This study was a normative research or doctrinal research. The results of the study shows that the provisions of death penalty in Indonesia is still enforced because have been regulated in the Criminal Code and several organic laws such as the law of terrorism, narcotics, corruption, and human rights justice. The death penalty is contrary to Article $28 I$ of the 1945 Constitution. It has set the rights to life, so that no one may violate human rights, including the government and the country is not granted the right to revoke rights for every citizen. The Indonesian government should not impose the death penalty contained in the draft new Code, and abolish the death penalty in its organic law that had been imposed on the offenders. Preferably, the death penalty may be replaced by alternative punishment with life imprisonment, a prison within a specified time or according to the judge's decision.
\end{abstract}

Keywords: Criminal Law; Death Penalty; Human Rights; Law Enforcement

DOI: 10.20956/halrev.v2i3.695

\section{INTRODUCTION}

Amnesty International recorded executions in 22 countries in 2014, the same number of countries as in 2013. Although the number remained constant, there were some changes in the countries carrying out executions. Seven countries that executed in 2013 did not do so in 2014 (Bangladesh, Botswana, Indonesia, India, Kuwait, Nigeria and South Sudan) while seven others resumed executions (Belarus, Egypt, Equatorial Guinea,
Jordan, Pakistan, Singapore and the United Arab Emirates [UAE]). Amnesty International was unable to confirm whether judicial executions took place in Syria. There were at least 165 people on death row in Indonesia at the end of 2015 , and more than $40 \%$ of those were sentenced for drug-related crimes. Of these, there have been 14 execution in $2015{ }^{1}$

Amnesty International. (2015). Death Sentences and Executions 2014. United Kingdom: Amnesty International Ltd., p. 5. 
Implementation of the death penalty in Indonesia gained more attention after Bali Nine execution on April, 2015. Many argumentation arise regarding to treatment of the death-sentenced, particularly, some of them must wait for execution in years. It is interenting from human right point of view. At its last, Universal Periodic Review in front of the UN Human Rights Council on 23 May 2012, Indonesia rejected recommendations to impose an official moratorium on the death penalty, despite not having executed anyone during the previous 4 years. It defended its retention of the death penalty as a punishment of last resort and insisted that it was used only for serious crimes. Indonesia resumed executions the next year in 2013, and executed 5 people without prior announcement, violating basic due process guarantees. As of December 2014, at least 130 people remained on death row, 64 of them for drug trafficking. ${ }^{2}$ Indonesia again attracted significant international attention when 14 executions were carried out in mid2015, all for drug crimes. ${ }^{3}$

Pros and cons of the death penalty that is implemented in Indonesia are always debatable because of most countries woldwide has abolished the death penalty. William A. Schabas stated that Even the most advanced international instruments dealing with the death penalty, the abolitionist protocols adopted by the United Nations, the Council of Europe and the Organization of American States, tolerate the death penalty during

\footnotetext{
Ibid., p.31.

World Coalition Against the Death Penalty (2015). Death penalty for drug crimes in Asia. (Report). FIDH, p. 27. Available online at: https://www.fidh.org/IMG/ pdf/asia_death_penalty drug_crimes fidh_wcadp_report_oct_2015_pdf Accessed on May 4, 2016.
}

wartime. 1 In the case of Protocol No. 6 to the Europea. ${ }^{4}$ However, it can be understood that the death penalty in Indonesia remain to be done, except to change the requirements of the law. According to the principle of legality in criminal law as stipulated in Article 1 of the Indonesian Criminal Code, that no crime can be committed, nor punishment imposed without a pre-existing penal law. The principle can be varyingly expressed in Latin phrases such as 'Nullum crimen, nulla poena sine praevia lege poenali'.

According to the principle of legality, then the implementation of the death penalty in Indonesia can not be avoided. Moeljatno stated that criminal punishment consists of the following principal capital punishment, imprisonment, and fined, while the additional penalty consists of the revocation of certain rights, deprivation of certain goods and the judge's verdict. The Indonesian Criminal Code prescribed some conditions governing the death penalty, such as Article 10 of the Criminal Code, Article 104 of the Criminal Code of treason, Article 111 paragraph (2), invites foreigners to invade Indonesia, Article 124 paragraph (3), notify the enemy in the war, Article 140 paragraph (3) treason against friendly countries, and article 340 of the Criminal Code of premeditated murder, the Criminal Code Article 365 paragraph (4) theft with violence and Article 444 Criminal Code of piracy at sea.

Jonkers said that has not been satisfied with the sentence of death that is set on the articles of the Criminal Code, as in the

\footnotetext{
$4 \quad$ William A. Schabas. (2002). The Abolition of the Death Penalty in International Law. [Online]. $3^{\text {rd }}$ ed. Cambridge: Cambridge University Press. Available from: Cambridge Books Online < $\underline{\mathrm{http}} / / / \mathrm{dx}$.doi.org/10.1017/ CBO9780511494109> [Accessed 26 June 2016].
} 
Netherlands has be fought the abolition of the death penalty, which raised doubts on the implementation of the death penalty in Indonesia. ${ }^{5}$ In addition, when prepared as the basic law, the 1945 Constitution, does not passed the law relating to the right to life to the citizens. The provisions of Article 27, 28, $29,30,31,33$ and 34 of the 1945 Constitution stated the rights of citizens simply. After the second amendment on 18 August 2000, recently set of human rights. During the revolution, Indonesian did not so questioned the applicable law, whether it was a colonial law or not. At the time it was considered not so urgent to discuss aspects of rights of livelihood fair and civilized in a constitutional state based on Pancasila, which is important at this time is how to repel invaders, unleash the economy, and implement an effective governance and so on. ${ }^{6}$

During situation was urgent that six months later in Yogyakarta, Sukarno, the President of the Republic of Indonesia, assigned a new set of Criminal Law, and known as the Law No. 1 of 1946 . This regulation applied only in Java and Madura and announced on February 26, 1946. Furthermore, through the Law No. 73 of 1958, Law No. 1 of 1946 was declared valid throughout Indonesia. ${ }^{7}$ After 54 years applies the death penalty in Indonesia, on August 18, 2000 there is a new provision regarding the right to life to citizens that constitutionally regulated through amendments to the 1945 Constitution of the Republic of Indonesia. It should have the right to life has been gov-

\footnotetext{
Jonkers as cited in Sahetapy, J.E. (2007). Pidana Mati dalam Pancasila. Bandung: PT. Citra Aditya Bakti, p. 27

Ibid, p. 125.

Ibid, p. 126
}

erned since the enactment of the Constitution on August 18, 1945. This is an issue that why first birth rules the death penalty in the penal code, then recently set right to life in the second amendment to the Constitution of the Republic of Indonesia in 1945, so that it becomes attractive for authors to conduct this study. This is an issue that has been enacted death penalty in the Criminal Code, then just set the right to live through the second amandment of the 1945 Constitution.

\section{ANALYSIS AND DISCUSSION \\ Theoretical Framework \\ Theory of Legal Certainty}

Lon Fuller stated that the definition of of legal certainty which refers to 8 (eight) the principles that must be met by law, namely: ${ }^{8}$

1) A law system that consisted of rules, not based on the decisions of the instantaneous certain things;

2) The regulation was announced to the public;

3) Not retroactive;

4) Created in a formulation that is understandable by the public;

5) There should be no conflicting rules;

6) There should not require an act that exceeds what can be done;

7) There should not always be changed; and

8) 'There should be compatibility between the regulations and the implementation daily.

Lon Fuller's opinion, that there should be legal certainty between regulation and its implementation, thus already entered the

\footnotetext{
Gunawan Wijaya. (2006). "Pembuatan Undang-Undang dan Penafsiran Hukum", Law Review, Fakultas Hukum Universitas Pelita Harapan, 6(1): 18-37.
} 
realm of action, behavior and the factors that influence how positive law run. Legal certainty contains two meanings, are: First, the general regulation, make people know what should or should not do; Second, the legal security for individuals from government authority because the general regulation, the individual is able to know what should be in charge or by the state to the individual. ${ }^{9}$

\section{Theory of Legal Protection}

Legal protection is the protection afforded to something, whether it was the people, things and everything else. Legal protection means the protection provided from the law in order not to be interpreted differently and not injured by law enforcement officials and also means the protection provided by the law against something. Law in accordance with the objective should be to provide protection to all parties in accordance with the status of his sentence because every person have equal status before the law as mentioned in the 1945 Constitution as a constitutional right. Every law enforcement officers are required to enforce the law to give legal protection to any legal relationship or from all aspects of community life.

Fitzgerald as cited by Satjipto Rahardjo stated that the theory of legal protection aims to integrate and coordinate the various interests in the community because of the wide range of interests, the protection of certain interests can be done by limiting the various interests on the other. ${ }^{10}$ According to Philip M. Hadjon that legal protection for the people associated with the formulation of

\footnotetext{
$9 \quad$ Ibid.

10 Satjipto Raharjo. (2000). Ilmu Hukum. Bandung: PT. Citra Aditya Bakti, p. 53
}

"legal protector of the individual in relation to acts of administrative authorities"

Legal protection for the people can be divided into two kinds of preventive and repressive legal protection. On preventive legal protection, the people are given the opportunity to raise objections (insproak) or his opinion before a government decision received definitive form. Thus preventive legal protection aims to prevent disputes while the protection of repressive laws aimed at resolving the dispute. ${ }^{11}$

Legal protection is the functioning of the law to realize the objectives of law, ie; justice, expediency, and legal certainty. Legal protection is a subject of the protection accorded to the law in accordance with the rule of law, whether it is preventive as well as in the form of a repressive, whether written or unwritten in order to enforce the law.

\section{Theory of Law Enforcement}

Law enforcement identical with law enforcement officials such as prosecutors, police and judges and lawyers. The law enforcement that is always done in the field of law enforcement and or community. Jimly Assiddiqie $^{12}$ mentioned that law enforcement is the process of doing an effort for the establishment or the functioning of the legal norms in the society. Soerjono Soekanto mentions several factors are factor law enforcement, law enforcement apparatus, means factors, community factors and cultural factors. ${ }^{13}$

\footnotetext{
11 Philipus M. Hadjon, (1987). Perlindungan Hukum Bagi Rakyat Indonesia. Surabaya: Bina Ilmu, p.2

12 Jimly Assiddiqie. (2013). Penegakan Hukum. (Paper). Available online at: http://www.jimly.com/makalah/namafile/56/Penegakan_Hukum.pdf Accessed on 16 July 2015.

13 Juniarso Ridwan and Ahmad Sodik Sudraja. (2009). Hukum Administrasi Negara dan Kebijakan Pelayanan Publik. Bandung: Nuansa Cendekia, p. 21
} 
In general, the law enforcement process involving all subjects of law in any legal relationship. Anyone who runs or normative or do something by basing itself on legal norms in force, meaning he runs or enforce the rule of law. ${ }^{14}$ In a narrow sense, the subject's it, that law enforcement officials only be interpreted as an attempt to ensure the enforcement of certain laws and ensure that a legal between running properly. In ensuring the rule of law, if necessary, law enforcement officials were allowed to use forced labor.

\section{Theory of Death Penalty}

The Constitution provides for rights to life and to remain free from torture that are "fundamental human rights that shall not be curtailed under any circumstance;" and the state must regulate and guarantee the implementation of fundamental rights through "laws and regulations." 15 Since 1945, Indonesia does not regulate the protection of the right of life to the citizens. Until 1946, enacted Law No. 1 of 1946 concerning the Indonesian Criminal Code which in several provisions concerning the death penalty. Chapter 11 of the Criminal Code expressed that the death penalty is executed by the hangman on a hanger with a rope tied to the gallows on the convict's neck, then dropped the board where the convict stands. In fact, the implementation of death penalty based on the Law No. 2/PNPS/1964 regarding the procedure for the implementation of death sentences imposed by the courts in the common judi-

14 Sudikno Mertokusumo. (2010). Mengenai Hukum Suatu Pengantar. Yogyakarta: Penerbit Uversitas Atmadjaya, p. 99

15 See, Article 28(A), 28(I) the 1945 Constitution of the Republic of Indonesia. cial system and the military, which imposed criminal by being shot to death.

Sahetapy. J.E. stated that the death penalty was initially done externally means to executed outside the prison walls. Form of implementation death penalty through a gallows with a hangman as executor. Deathsentenced is executed in the open field, hanged on the gallows as a kind of deterrent. ${ }^{16}$ In the death penalty does not necessarily every defendant should be sentenced to death, but there is an alternative way to impose the death penalty. Adamichazawi states that is available alternative punishment, the judges do not always have to impose the death penalty for crime punishable the death penalty. Judicial independence, free to choose impose life imprisonment or temporary imprisonment, depending on many facts considered in the event of crimes committed concretely. ${ }^{17}$

The law establishes an alternative punishment for any death sentences have been threatened with the formulation of the crime on the basis that any criminal offense which carries a death penalty, in certain circumstances or boost factors that are lightened. According to the sense of justice, judges inappropriate for the death penalty, the judge can impose any other punishment as an alternative, so that was not the only death penalty in law enforcement but depending on the severity of the crime committed by someone.

The death penalty in the literature and dictionaries are not found understanding, except in the Regulation of the Chief of Police

\footnotetext{
Sahetapy, J.E. Loc.Cit.

17 Adami Chazawi. (2010). Stelsel Pidana, Tindak Pidana, Teori-teori Pemidanaan dan. Batas Berlakunya Hukum Pidana. Jakarta: PT. RajaGrafindo Persada, pg. 31-32
} 
No. 12 of 2010 on the Implementation of Death Penalty. The death penalty is one of the principal penalty imposed by the judge to the convict who has obtained legally binding. The death penalty is a sanction or punishment for perpetrators of crimes committed by a person based on the decision of court judges. According to the retributivism theory, the point is the legal punishment is justified legally and ethically, as a retribution for the violation or losses that have been inflicted on others. Retributivism theory and purpose retaliation perpetrator's actions.

Kant and Hegel gives four reasons ethical justification on retributivism or retaliation, namely; First, the moral right to punish someone solely on the basis of the crimes he is convicted of a mistake or a crime. Second, the moral obligation to punish exclusively and firm on the same runway. Thirdly, for the sake of justice Retributivism, then the punishment must be balanced with the weight of mistakes that have been made. Fourth, the basic moral judgment is that punishment is a recovery to errors and reafimasi against sentence are violated, punishment is also the rights of the offender.

In the Universal Declaration of $\mathrm{Hu}-$ man Rights states that all human beings are born free and equal in dignity and rights. man endowed with reason and conscience and should act towards our fellow human beings in a spirit of brotherhood. Likewise mentioned in the formulation of Article 1 paragraph 1 of the Law No. 39 of 1999 concerning Human Rights, stated that the human right is a right inherent in man as a creature of God Almighty that must be respected, up- held and protected by the state, law, government, and everyone for the respect and protection of human dignity. Human rights are fundamental rights of human beings during life and after and can not be revoked by arbitrarily without any provisions of applicable law. Human rights are not a gift from the state and human law. Then, to maintain and achieve it, requires a collective struggle by way of a constitutional and political.

According to Frans Magnis said that the basic concept of human rights have two dimensions of thought, namely: First, universality dimension. Human rights will always be needed by anyone and in the aspect of culture wherever it is, whether it's on the western and eastern cultures. The human rights dimension in this perspective, essentially will always be needed, and a means for Indonesia to express himself freely in the bonds of social life. In other words, human rights are human beings as man, so as far as the human species 'homo sapiens', and not because of certain characteristics possessed; Second, contextuality dimension, which concerns the application of human rights when reviewed from a place the enactment of the human rights, referring to the ideas of human rights can be applied effectively, along the place of ideas can be applied to human rights and the foundation of ethics in human relationships. ${ }^{18}$

From these two dimensions is expected there will be no human rights violations by any person, government and even the state is not allowed to violate human rights. Peter R. Baekr stated that now so many discourses

\footnotetext{
18 Hestu Cipto Handoyo. (2003). Hukum Tata Negara, Kewarganegaraan dan Hak Asasi Manusia. Yogyakarta: Penerbit Universitas Atmadjaya, p. 271
} 
are expressed every day deals with the idea or opinion on human rights. However, at the same time so many violations around the world. Human rights are a legal issue, but this issue has developed into a political issue, lawyers, politicians, governments, nongovernmental organizations, other. Women, parents or children, victims and offenders, everything is included in a human rights issue. ${ }^{19}$

Human rights in international context got a recognition as stated in the Charter of the United Nations through the preamble which stated that in order to strengthen human rights, in the dignity of man, the same rights, both men and women and for all nations, large and small, and in order to wake a state, in which justice and respect for the obligations arising from treaties and other sources of international law can be maintained. In international human rights is the recognition of the values, standards, or rules on regulating the behavior of the state towards its citizens or not. Therefore, human rights are the most appropriate when it is understood as a guide obligation for the government as well as individuals. ${ }^{20}$

\section{Implementation of the Death Penalty in Indonesia}

The death penalty is a provision of positive law. In the Netherlands, the death penalty has been removed since 1870 . However, the death penalty is retained in Indonesia, when it should be the death penalty had to be abandoned. The Indonesian Criminal Code in force a product of the colonial, and therefore

\footnotetext{
19 Peter R. Baekr. (1999). Human Rights University in Practice. London: Macamilan Press, p. 1

$20 \quad$ James W. Nickel. (1996). Hak Asasi Manusia, Making Sanse of Human Right. Jakarta: Sunprinting, p. 86
}

is proper that some provisions of the death penalty in the Criminal Code was abolished. The legal basis for the implementation of the death penalty in Indonesia if it is reviewed from the 1945 Constitution is very contradictory as stated in the second amendment of that Article 28I and the Law No. 39 of 1999 on human rights.

The death penalty is certainly not the same as death, but always associated with death if people talk about the death penalty. The death penalty is the only way to reduce crime, it must be answered that no, in fact drug-related crime and terrorism has not diminished. There is a presumption that the sentence of death for a criminal act, then people will not dare to do the deed. So, too naive assumption because it departed from the views were not understood human problems and crime as well as the structure of society, even crime increasingly. ${ }^{21}$

Article 4 of the Law No. 39 of 1999 concerning Human Rights stated the right to life, but on the other hand, Article 36 of the Law No. 26 of 2000 concerning Human Rights Court provides that any person who acts as stipulated in Article 8 letter a, b, c, $\mathrm{d}$, e, shall be punished by death. Implementation of Death Penalty in Indonesia should be still required the harmonization of its laws and regulations because the Indonesian Criminal Code has several provisions to regulate the death penalty and also in the organic law such as the law of terrorism, narcotics, corruption, and human rights court.

The issue of the death penalty continues to be a main topic in the community, because anyone agree with the death penalty

Ibid, p.80 
and some are not agreed. Among the humanitarian activists will remain opposed to the death penalty for any reason, but the struggle would always be in vain, if there is no harmonization of its legislation or remove the death penalty provision in the Criminal Code and some of the organic law regarding the death penalty. The use of the death penalty was challenged in front of the Constitutional Court in 2007 specifically on its applicability for drug crimes, and again in 2008 regarding the methods of execution used in Indonesia. In both cases, the Court decided after judicial review that the use of the death penalty in Indonesia is not unconstitutional. ${ }^{22}$

Colman Lynch argues that, though Indonesia had a legal obligation to abolish capital punishment as a punishment for drug-trafficking crimes under its constitution and applicable international law. As interpreted by relevant international bodies, its judiciary was able to find sufficient ambiguity in the wording of each obligation to buck the international trend of abolishing capital punishment. Furthermore, it argues that this result was partly due to factors which inhibit free and open debate on capital punishment in Indonesia. Part I of this Note will explain the Bali Nine case, applicable law, and the events leading to their appeal to the Indonesian Constitutional Court. Part II will describe the Indonesian Constitutional Court and the arguments made by each side. Part III will examine various extralegal factors which may have affected the Constitutional Court's decision and which generally restrict Indonesia's debate on capital punishment.

22 FIDH, World Coalition Against the Death Penalty. Op.Cit. p. 28.
Part IV will explain and analyze the majority opinion and dissents from the Constitutional Court's decision. Finally, Part V will conclude that the Indonesian Constitutional Court was able to find sufficient ambiguity in the wording of the 1945 Constitution and the ICCPR to allow capital punishment for drug-smuggling offenses, that this took place in part because the ICCPR lacked binding power, and that for capital punishment to be abolished in Indonesia, more debate-and more open debate on the subject will be necessary. ${ }^{23}$

I Dewa Gede Atmadja, said that there are philosophers who agree to the death penalty and also there who disagree imposition of the death penalty. ${ }^{24}$ Some philosophies that justify the death penalty, are:

1) A guilt that have been proved legally is the only basis for the state agencies for eligible and obliged to punish according to justice in a sense proportionate to his guilt, and the death penalty can be justified and fair to murder for balanced with errors kill a fellow human being (theory of retributivism).

2) The death penalty for deterrence and deterrence. In order for the function of the death penalty carries a deterrent effect and deterrence, then the execution is carried out openly in front of the pubic or at least be exposed widely to the public, causing maximum impact to the community (theory of utilitarianism).

23 Colman Lynch. (2009). Indonesia's Use of Capital Punishment for Drug-Trafficking Crimes: Legal Obligations, Extralegal Factors, and the Bali Nine Case. Linch Final Formatted.doc. p.252

24 I Dewa Gede Atmadja, Op.Cit, p. 114-115 
3) The emphasis on public safety purposes, the death penalty is deemed a positive effect on deterrence and containment (John Stuart Mail in perlianmentary debate, 28 April 1968).

4) State as the highest intensity, because of it is authorized to impose the death penalty for crimes that take the life of another person, because the murder is to eliminate the existence of a whole human being (Hegel).

5) The death penalty is legal and fair kind of punishment against the crime of murder, because no retributive punishment be proportionate, unless the death sentence should be imposed immediately to the perpetrator (Immanuel Kant).

On the other side, some philosophies that refuse the death penalty are:

1) Psychological reasons, that the death penalty is not create the deterrent effects and deterrence or prevention, as the death penalty does not give long and deep impression of to the people (Beccaria refusal on the argument of Bentham utilitarialisms). Beccaria proposed instead of the death penalty to life imprisonment.

2) Reason based on the concept of the right to life, which views the death penalty is a violation of human rights which must diindungi including the murder though (Primoratz, Jatifying Legal Punishment).

3) Reason based on the concept of the right to life, which views the death penalty is a violation of human rights and must be protected, even by the murder (Primoratz, Jatifying Legal Punishment).

4) The reason the sanctity of life, the most fundamental argument against the death penalty is based on the belief the sanctity of life. Historically the belief in the sanctity of life evolved through three grooves meaning, namely:

a. Life comes from God, the creator. therefore its sublime, so humans do not have the power to pull it out.

b. Nobleness understood as the right to life and life must be protected existence.

c. Nobility of life is understood in the form of values that give the infinite dignity of man, incomparable and absolute nature. On the basis of the third meaning of nobility on the sanctity of life, this philosophical adherents reject the death penalty, are; the grooves for the first understanding (rejection of the clergy against the death penalty), the second grooves (rejection of secular humanists against the death penalty), the third one is coming from rejection of the intellectuals on the death penalty.

5) The most important reason is now developing against the death penalty is the argument that the death penalty is contrary to humanity.

In society, experts, politicians, NGOs and humanitarian activists, always experienced a controversy on justification and rejection of the death penalty, even though parts of the world is already quite a lot of countries are abolishing the death penalty in 
their positive law such as Belgium (1867), Portugal (1867), Sweden (1921), Australia (1922-1968), Mexico (1928), Denmark (1930), Brazil (1946), Italia (1948), Germany (1450), Israel (1954), New Zealand (1961), England (1965), Vatican (1969), Canada (1976), and France (1981), even the Netherlands has abolished the death penalty since the 19th century (1818).

Agree or reject the death penalty can also be viewed from the events experienced by the victims or their families. If people have not been exposed to the problem of evil has always rejected the death penalty, and vice versa, especially if the family became victims brutally murdered and victimized by terrorist bombings. The death penalty is a cruel form of punishment and not harmonious with the ideals of human beings in the process of cultural development. ${ }^{25}$ The opinion states that the implementation of capital punishment in any method of the prisoners still suffering. Criminal in a civilized criminal law can not and should not be confused with vengeance, vengeance means that a criminal should not be imposed based on emotion or is cruel or is suffering indefinitely.

\section{The Death Penalty: A Human Rights Perspective}

Since its conception, man has obtained rights until he is born in the world even to death. Rights as human beings should meet, because after all as human beings should be treated in a manner that is humane. From the aspect of human rights that the death penalty is contrary to the right to life, so it is

25 Djoko Prakoso. (1987). Masalah Pidana Mati, Soal Jawab. Jakarta: Penerbit Bima Aksara, p.83 feasible to take the lives of humans is only God and not through human intermediaries, governments and countries. In Qur'an 6:151 which means do not kill the life which Allah has forbidden, except with a great cause. The verse indicates the right to life for human beings regardless of differences in religion, race or nation and country. ${ }^{26}$ Looking at verses of the Qur'an, then the absolute human rights to be maintained and should not be disturbed, except with a great cause for example riots, rebellion, gangs, terrorists, did escape from lawful detention, and committing a crime that weight based on the decision that was binding.

Human rights are a set of rights attached to nature and human existence as a creature of God Almighty and the grace that must be respected, in high Junjun and diindungi by the state, law, government and everyone for the respect and protection of human dignity. Human rights are the natural right of any kind should not be reduced and broken by anyone because the human rights are rights inherent to the human being, without it men is impossible to live as human beings. John Locke as cited in Nickel, stated that human rights are the rights given directly by God almighty as a natural right. ${ }^{27}$

In the laws and regulations in Indonesia, the death penalty other than as set out in the Criminal Code is set also in the organic legislation, such as; The Law No. 1 of 2003 concerning Terrorism Crime, in Article 6 expressed that any person who intentionally or threat of violence lead to an atmosphere

\footnotetext{
26 Michael Mumisa et al. (2015). Sharia Law and the Death Penalty: Would Abolition of the Death Penalty Be Unfaithful to the Message of Islam?. UK: Penal Reform International, p. 10

27 James W. Nichel. (1996). Op.Cit., p. 118
} 
of terror or fear of the widespread or cause the victim that is mass, by robbing the independence or the loss of life and property others, or cause a riot or disturbance to vital objects are located or to the environment or public facilities or international facilities, in the criminal with death penalty or life imprisonment. Likewise, Law No. 31 of 1999 jo. Law No. 20 of 2001 concerning Eradication of Corruption, in Article 2, paragraph (2) in the case of corruption as referred to in Article 2 paragraph (1) shall be done in certain circumstances, the death penalty can be imposed and the elucidation. In addition, the Law No. 22 of 1997 concerning psychotropic substances in Article 80-82 set the death penalty for violating these provisions. Regarding human rights court as stipulated in Article 7-9 of the Law No. 26 of 2000 against perpetrators of crimes of genocide and crimes against humanity punishable by death penalty.

Looking at laws concerning the death penalty, is not absolute under these provisions that the death penalty is the only way to punish someone who committed crimes, there is still an opportunity for human rights to be upheld and the judge was as a holder of justice to uphold human rights, the judge can choose the appropriate penalty imposed on the offender by considering the values of human rights. Executed many of the perpetrators, not the proudest, even greater concern affects people, nations and countries. Criminal law on the death penalty could be used as a "ultimium remedium" or means the last, regardless of the pros and cons of using the death penalty. From the criminology approach, the death penalty will not solve the problem either means retributive and as a means deterent.

The death penalty is not carried out at the time of the decision of enforceable but delay it without a clear deadline for execution. The delay was actually also a form of punishment. Although, not in the sense in today's juridical, delaying the execution of a kind of human rights violations. For example, the implementation of the death penalty on Kusni Kasdut and Hengki Tupanawael had to wait for 25 years for their execution.

European Convention in November 4, 1950 on human rights, in Article 2 paragraph (1) reads that everyone's right to life shall be protected by law. No one may be deprived of his life intentionally except in execution of a judgment of the court after it was decided that he had committed a crime that is subject to penalty as such by law. ${ }^{28} \mathrm{Kuk} \mathrm{Cho}^{29}$ stated that it is important to note that it is not just civic organizations that have begun to favor abolition of the death penalty but also state organizations including the National Assembly and the National Human Rights Commission. The Constitutional Court has invalidated some disproportionate provisions in relation to the death penalty.

At the end of this paper, for whatever reason the right to life is a human right that must be respected and hold in high regard, by law, the nation, the state and every person as well as the community groups. Should not deprive the right to life, but with a great cause and under a court decision that has binding.

28 Ibid., p. 271

29 Kuk Cho (2008). "Death Penalty in Korea: From Unofficial Moratorium to Abolition?" Asian Journal of Comparative Law, 3(1): 1-28. Doi: 10.1017/ S2194607800000120. 


\section{CONCLUSION}

The death penalty in Indonesia today is still enforced because it is still regulated in the Criminal Code and several organic laws such as the law of terrorism, narcotics, corruption, and human rights. The death penalty is contrary to Article 28I of the 1945 Constitution. It has set the rights to life, so that no one may violate human rights, including the government and the country is not granted the right to revoke rights for every citizen. Require the harmonized of legislation in force in Indonesia against the death penalty, because the legislation one another conflicting. The Indonesian government should not impose the death penalty contained in the draft new Code, and abolish the death penalty in its organic law that had been imposed on the offenders. Preferably, the death penalty may be replaced by alternative punishment with life imprisonment, a prison within a specified time or according to the judge's decision.

\section{BIBLIOGRAPHY}

Adami Chazawi. (2010). Stelsel Pidana, Tindak Pidana, Teori-teori Pemidanaan dan. Batas Berlakunya Hukum Pidana. Jakarta: PT. RajaGrafindo Persada.

Amnesty International. (2015). Death Sentences and Executions 2014. United Kingdom: Amnesty International Ltd.

Colman Lynch. (2009). “Indonesia's Use of Capital Punishment for Drug trafficking Crimes: Legal Obligations, Extralegal Factors, and the Bali Nine Case." Columbia Human Rights Law Review 40: 523-27.

Djoko Prakoso. (1987). Masalah Pidana Mati, Soal Jawab. Jakarta: Penerbit
Bima Aksara.

Gunawan Wijaya. (2006). "Pembuatan Undang-Undang dan Penafsiran Hukum", Law Review, Fakultas Hukum Universitas Pelita Harapan, 6(1): 18-37.

Hestu Cipto Handoyo. (2003). Hukum Tata Negara, Kewarganegaraan dan Hak Asasi Manusia. Yogyakarta: Penerbit Universitas Atmadjaya.

James W. Nickel. (1996). Hak Asasi Manusia, Making Sanse of Human Right. Jakarta: Sunprinting.

Jimly Assiddiqie. (2013). Penegakan Hukum. (Paper). Available online at: http://www.jimly.com/makalah/namafile/56/Penegakan_Hukum.pdf Accessed on July 16, 2015.

Juniarso Ridwan and Ahmad Sodik Sudraja. (2009). Hukum Administrasi Negara dan Kebijakan Pelayanan Publik. Bandung: Nuansa Cendekia.

Kuk Cho (2008). "Death Penalty in Korea: From Unofficial Moratorium to Abolition?" Asian Journal of Comparative Law, 3(1): 1-28. Doi: 10.1017/ S2194607800000120.

Michael Mumisa et al. (2015). Sharia Law and the Death Penalty: Would Abolition of the Death Penalty Be Unfaithful to the Message of Islam?. UK: Penal Reform International. Downloadable at: https://goo.gl/S1CbZy Accessed on May 12, 2016.

Peter R. Baekr. (1999). Human Rights University in Practice. London: Macamilan Press.

Philipus M. Hadjon, (1987). Perlindungan Hukum Bagi Rakyat Indonesia. Surabaya: Bina Ilmu. 
Sahetapy, J.E. (2007). Pidana Mati dalam Pancasila. Bandung: PT. Citra Aditya Bakti.

Satjipto Raharjo. (2000). Ilmu Hukum. Bandung: PT. Citra Aditya Bakti.

Sudikno Mertokusumo. (2010). Mengenai Hukum Suatu Pengantar. Yogyakarta: Penerbit Uversitas Atmadjaya.

William A. Schabas. (2002). The Abolition of the Death Penalty in International
Law. $3^{\text {rd }}$ ed. Cambridge: Cambridge University Press. Available from: Cambridge Books Online <http://dx.doi. org/10.1017/CBO9780511494109> Accessed 26 June 2016.

World Coalition Against the Death Penalty (2015). Death penalty for drug crimes in Asia. (Report). FIDH. Available online at: https://goo.gl/4QBaek Accessed on May 4, 2016. 